\title{
INTERROGATING CONCEPTIONS OF 'MODERNITY' AND 'TRADITION' IN THE PRODUCTION OF THE BUILT ENVIRONMENT IN SOUTH ASIA•
}

\author{
Sarwat Viqar*
}

\begin{abstract}
It has been argued that concepts of modernity and tradition are historical categories that emerged in the context of imperial encounters with the 'other' during Colonization. This paper will show how the contingent nature of these categories becomes apparent when considering the production of the built environment in South Asia.
\end{abstract}

The advent of British Colonialism in the $18^{\text {th }}$ century precipitated a significant change in the urban landscape of South Asian cities. It also created a binary conception of a modern order that was a break from the local or native order of space. From then on, modernity became the institution of a liberal western order and tradition was what was retained by the natives that had been eclipsed by the new order. This trope of the dysfunctional Pre-Modern entered into native, nationalist imaginings of the past as well by establishing a binary between what was and what came after as being forever opposed to each other. In order to assert one, the other had to be negated. The Imperialist narrative achieved this through asserting the inherently moral nature and legitimacy of the Colonial order while the Nationalist narrative strove to recover the 'tradition' that had been displaced by the Colonial order. The modern disciplines introduced with Colonial rule did provide a powerful prescriptive model of urban planning that created a privileged position for what has come to be seen as the modern form of the city. However, drawing upon contemporary South Asian urban historiography and research it is argued here that this order was constantly destabilized by native resistance, appropriation, hybridity and accommodation. In doing so, it appears that the production and reproduction of space in the built environment of South Asia constantly challenges notions of a dynamic, all-consuming modernity against a static tradition that needs to be preserved.

Keywords: Modernity, tradition, colonial, culture

\section{INTRODUCTION}

The question of preserving the traditional built environment inevitably brings up the problem of how something is deemed traditional and hence worthy of preservation. For PostColonial historians working on the Sub-Continent, attempts to preserve the materiality of the past become a problem when they fall into a romanticism that manifests either as a nativism which advocates a return back to the 'roots', or as a nationalism that strives to rewrite histories in the service of nation-building, or as the nostalgia of a bourgeois class striving to distance itself from the monotony of a uniform modernity. Part of this problem is the casting of the traditional against the modern - a result of the way history itself is imagined in the subcontinent.

As Chakrabarty (1992:24) suggests, the 'transition narrative' in writing histories in South Asia presumes a fundamental point of historical rupture which is the Colonial encounter. This encounter achieved two things: on the one hand it established a Pre-Colonial world and order that was supposed to have skidded to a halt at the moment of encounter; on the other it was supposed to have launched the Colonized world on a new path of self-realization that would bring it in line with the liberal, modern order of the west. From then on, the binaries of native/non-native, Colonial/Pre-Colonial, despotic/liberal, civilized/non-civilized entered into the very way that Indians conceived of their reality, including the built environment.

\section{THE COLONIAL MIND-SET}

The values and mind-set that informed Colonial governance is illustrated very well in the writings of British travelers, geographers and even military men from that period. For example, in Sindh and the Races that Inhabit the Valley of the Indus, Burton (1851), after laying out the general state of 'decline' of the inhabitants of the region of Sindh suggested

- This paper was presented in the the 6th Seminar on Urban and Regional Planning, 2011, organized by the Department of Architecture and Planning, NED University of Engineering and Technology.

* Sarwat Viqar, Faculty Member, John Abbott College, Humanities Department. 


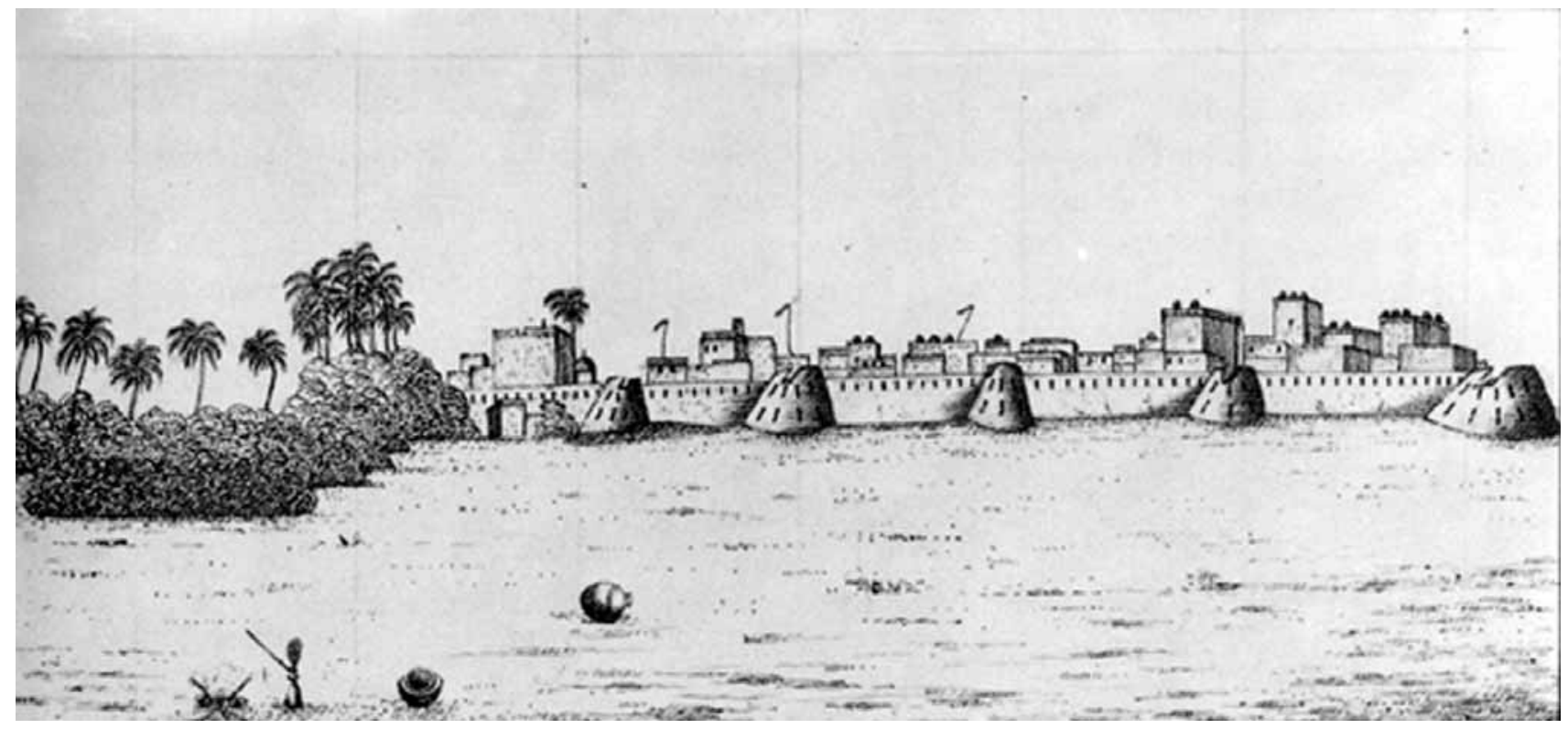

Figure 1: View of Karachi Circa 1830.

Source: Aijazuddin (1992)

that "the means of restoring health and vigour to the system are always in our hands." Another quote from Baillie (1890) referred to the Port of Karachi and attributed its sudden development to "the infusion, into its languid trade, of the commercial spirit of its invaders" (Baillie, 1890:2). According to Baillie (1890:7) it was also a city that "can hardly be said to possess a history." Baillie's monograph further went into great detail in terms of establishing the historic point of origin of the city of "Kurrachee." It is interesting to see how his investigation into the historic origins of the city took as its basis local accounts of its origin and went into painstaking detail in interrogating the credibility of these accounts. He then corresponded these accounts with the physical topography of the area. In the end, this exercise led him to discount many of these accounts as having weak foundations because of the "worthlessness" of "unwritten evidence handed down from generation to generation" (Baillie, 1890:8). In this way, local histories, largely based on oral traditions were not seen as real histories. As Chakrabarty (1992) has suggested, history became knowable only with the advent of modernity, for which, read the modern order of European liberalism.

The planning practices of Colonial rule also assumed these binaries in order to serve the purpose of empire building. For example, the idea of improving the landscape so that it fulfilled the objectives of British rule is to be found in much of the writing from the period (Arnold, 2006). On the one hand it established the outside gaze of the observer as the

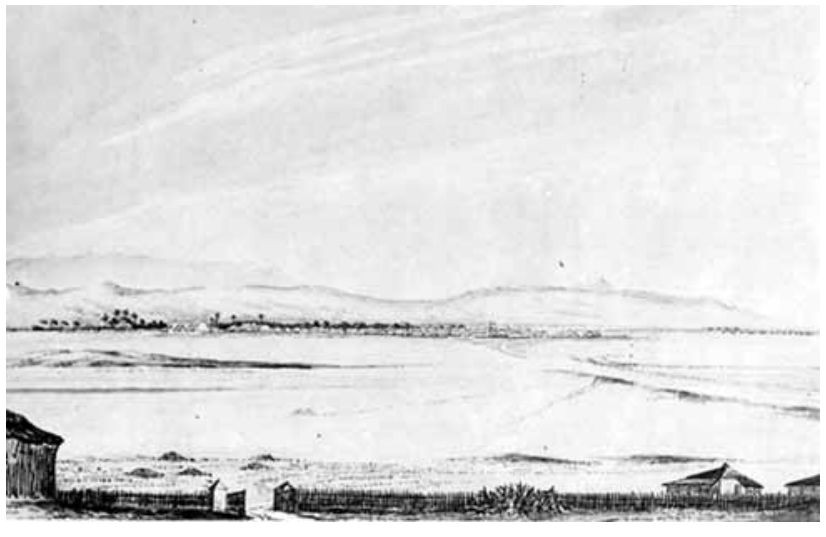

Figure 2: Karachi seen from Clifton, 1851.

Source: Aijazuddin (1992)

authority on what the land was as well as the values that inhere in it (Figures 1, 2). On the other, it became a justification for the transformation of the land into something that conformed to the desires of the observer. The land was supposed to be transformed for improvement and productivity but there was also a need for constant justification of the benefits that this intervention would bring to the local population (Figures 3, 4). It was important for the Colonial power to be seen as instituting a liberal, modern order and one way that this concern was expressed was the way the form and character of local life and local ways was represented. Local culture and ways of life were portrayed in such a way as to constantly provide a contrast to Colonial rule, thus helping to establish the basis of Colonial legitimacy. 


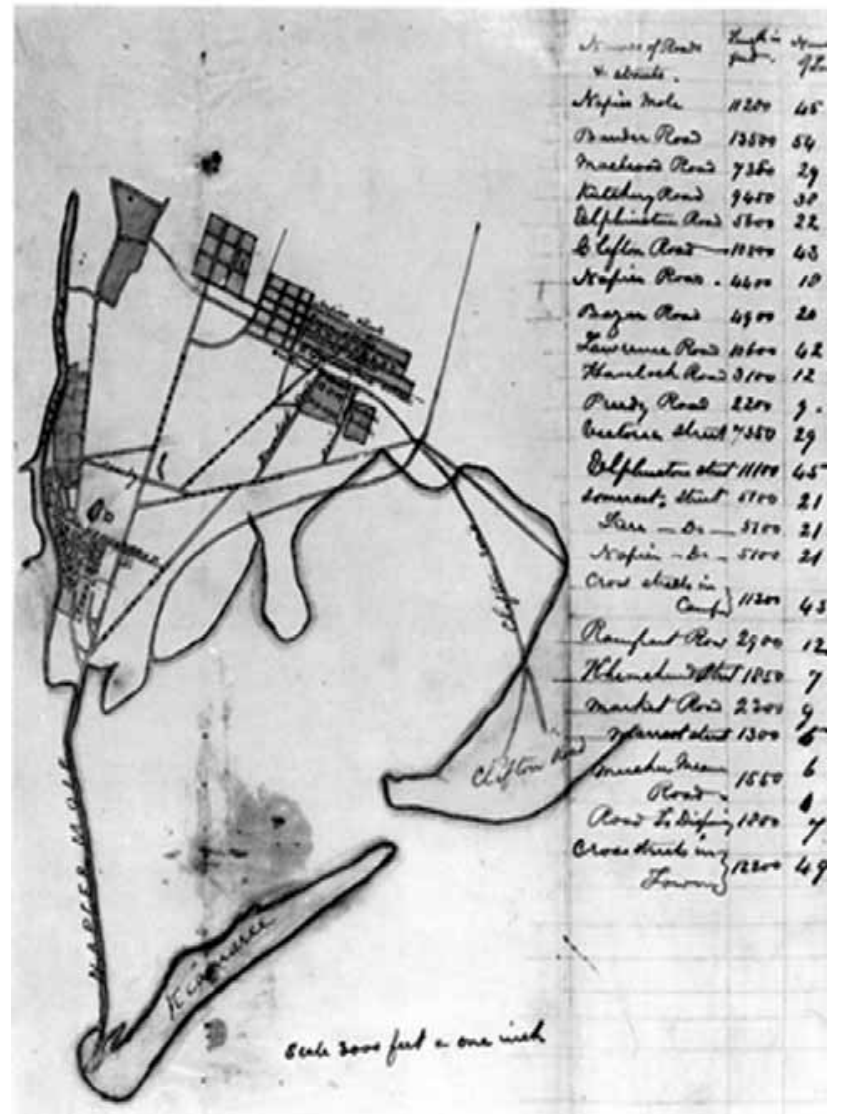

\section{ARCHITECTURE AND URBAN FORM}

In terms of spatial orders and built form, the building of institutions that represented the civilized order of the British became important. These included town halls, museums, churches and schools along with sanatoriums, prisons and barracks. The establishment of sanitation was an important priority for the Colonial regime. The existence of an efficient sanitary system came to symbolize the effectiveness of Colonial rule on several levels. Arnold (2006) has suggested that the issue of disease and medicine as it affected Indians became important for the British when their power had grown to such an extent as to require more scrutiny and control of Indians. At this time the nature and durability of British rule in India had become a practical concern.

In the same way architectural forms were also used to create an imagined past for India. Metcalf (1984) refers to the Indo-Saracenic style of architecture as an invention of British architects which was considered a representation of what the British thought should be an appropriate past for India. In this way Indian people became an audience for Britain's architectural activity and the Indo-Saracenic style became a trope for telling the story of India's past to the Indian people (Figures 5, 6).

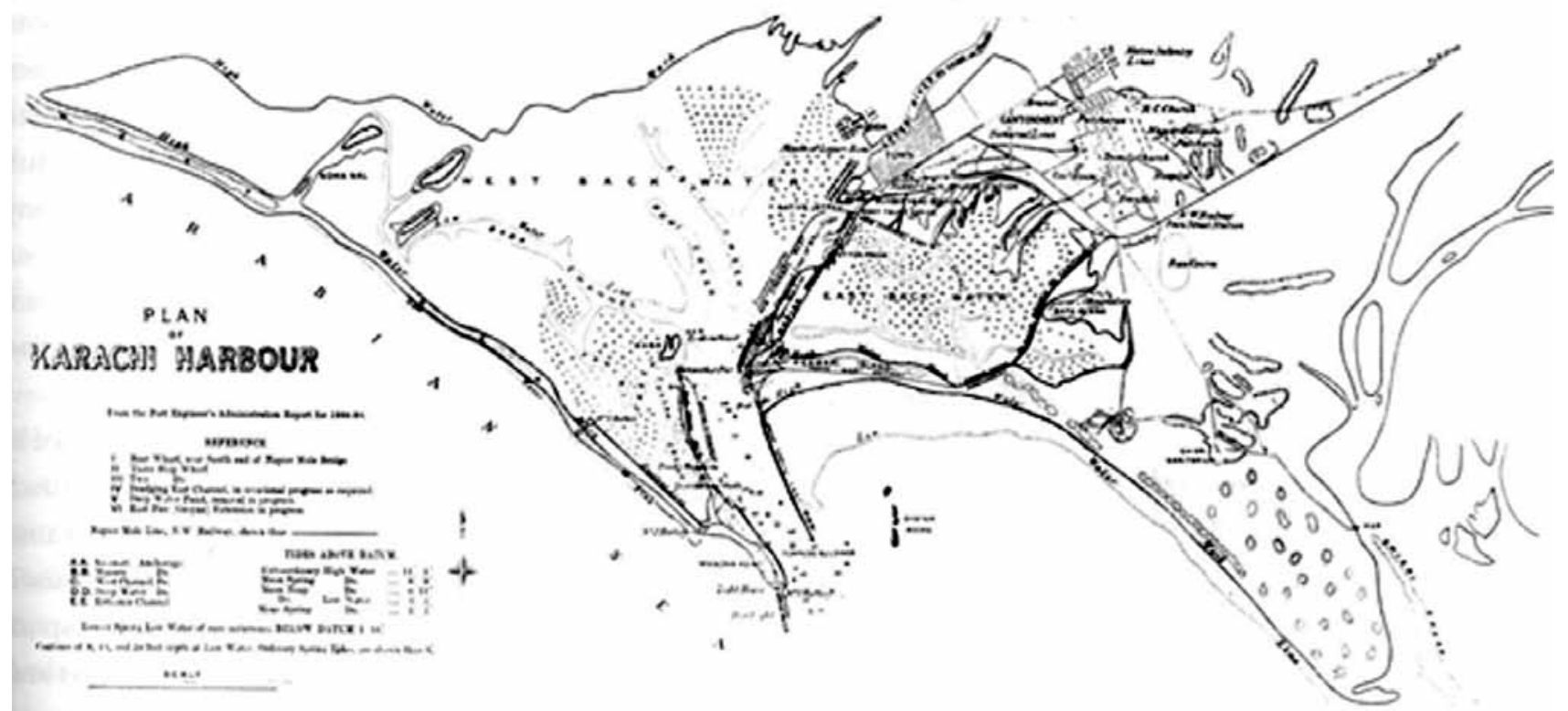

Figures 3, 4: The transformation of Karachi under British Rule. Source: Aijazuddin (1992) 


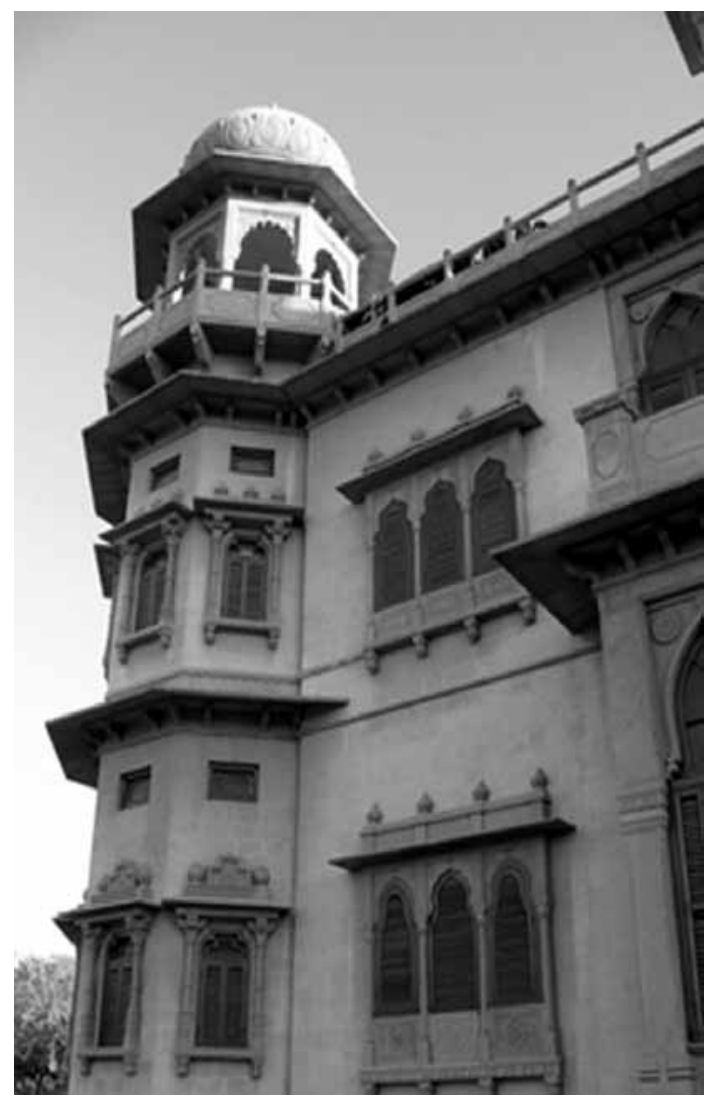

Figure 5: Mohatta Palace in Karachi.

The objective of the empire was to control the Colonial peoples and their past, not just the future. Through the census, surveys and ethnographic accounts, the range of India's architectural heritage became known. The British attitude then became one of ownership of this past as they were the ones who had laid it bare for the first time, in their own fashion. Thus a process of classification of Indian architecture began. This classification created a knowable history of Indian architecture that could be analyzed and critiqued. However it is the terms of this classification and the assumptions behind it that reveal its subjective nature. As Metcalf (1989:9) suggests, Imperial Architecture was an architecture of both power and knowledge: "To rule, one had to master, by ordering and labeling, that which one had conquered; to know was, in some measure, already to rule." In the construction of India's past, its imperial rulers identified the two dominant markers of Indian identity as caste and religion. India was also divided into two categories of population: Hindus and Muslims. This dichotomy found its way into classifications of architecture as well where the variety of architectural styles were either fit into the Saracenic i.e. Muslim style or the Hindu style. The problem was that

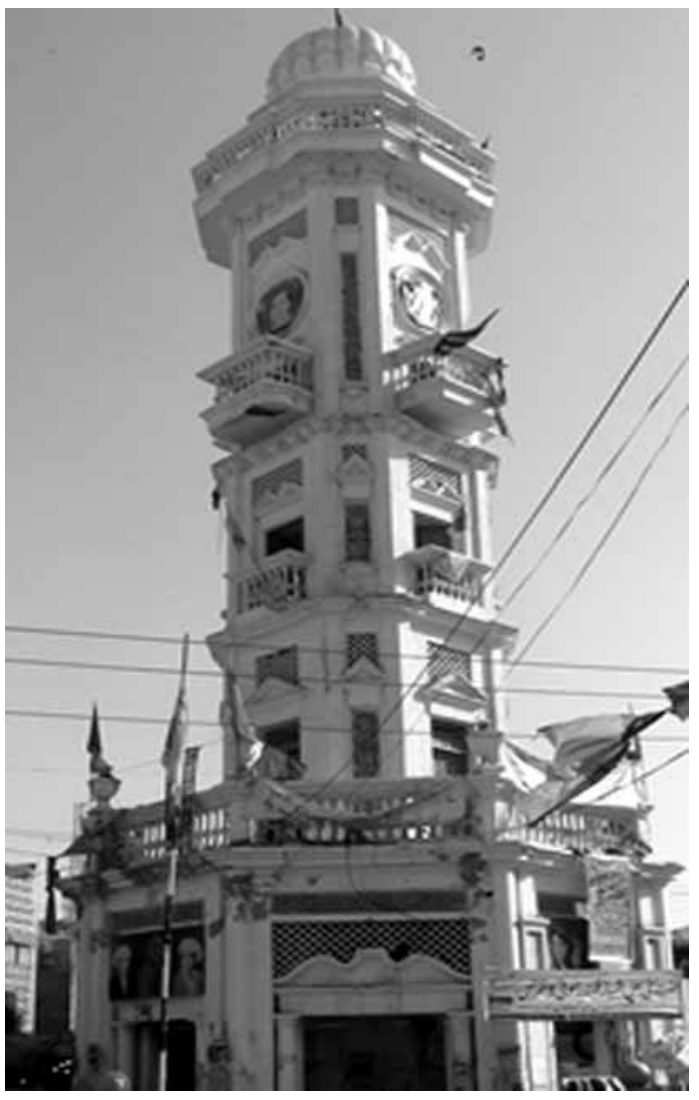

Figure 6: Clock tower in Shahi Bazaar, Sukkur.

this classification assumed the "centrality of a religious identity, which took shape in fixed architectural styles, defined an India that was in effect an "Orientalist" construct: a timeless land of tradition-bound peoples for whom religion alone had meaning" (Metcalf, 1989:41). This 'fixing' of built form into an unchanging cultural and religious identity denied the reality of the production of the built environment. A reality in which forms and their cultural meanings and identities arose from multiple sources, fused and diffused and produced new meanings.

As an example of Colonial interpretations of local spatial practices, the problem of the private and public use of space for the Europeans became a problem of legibility. Chattopadhyay (2006) suggests that the inability of the Europeans to decipher the way public and private spaces were configured in native spaces led to a rejection and condemnation of these spaces. By contrast, the white part of town was visually transparent and the boundaries between what was public and what was private were clearly coded and legible for the Europeans. For example, in the native neighbourhoods, the outer envelope of the house had very 
little exposure to the street outside while at the same time there were no private spaces in the house. It was noted by European observers that there were sometimes no locks on the doors, or sometimes no doors, and the two practices were seen as contradictory and hard to understand. This is because although this spatial configuration contained notions of private and public it was not in a way that conformed to the Colonial notions of what should be private or public. For the European, the interiority of the house was a gradual withdrawal into individualism, and as one moved towards the outside of the house one opened up to the world. The native house turned away from the street and arguably created a communal and 'public' world inside the house.

In this Colonial construct, Indian history occupies a position of sublaternity, forever seen through the lens of a universalized, Europe centered history. This theme finds its way into representations and meanings of South Asian cities as well. The imperial narrative historicized Colonial cities as having originated in the Colonial rule and having achieved their heyday under Colonial administration. The existence of prior settlement and trade in the area were not just disregarded but were also placed within the framework of the Pre-Modern which was cast as chaotic, undeveloped and uncivilized. Trade was not free and despotic powers limited free economic development, until the advent of Colonial rule (Blake, 1990). True autonomy and public life were missing. In other words, these were not cities in the true sense of the word. This trope of the dysfunctional PreModern entered into native, nationalist imaginings of the past as well by establishing a binary between what was and what came after as being forever opposed to each other. In order to assert one, the other had to be negated. The Imperialist narrative achieved this through asserting the inherently moral nature and legitimacy of the Colonial order while the Nationalist narrative strove to recover the 'tradition' that had been displaced by the Colonial order.

It is obvious that a historicization of the built environment of South Asia has to take into account both the Pre-Colonial order as well as the Colonial. However it is interesting to see how the Colonial order had presented itself as the instigator of modernity in this region. And it is true that the markers of what is seen as South Asian modernity originate in this history. In the built form, this included schools, hospitals, town halls and churches as "adjuncts of European civilazation" (Baillie, 1890:70). Politically the inception of the categories of the state, civil society and the bourgeois family accompanied the material form of the institutions that represented them.
Chattopadhyay (2006) problematizes modernity in the context of the Colonial city by critiquing the placing of modernity either as the unrealized potential of a universal western idea or one possible manifestation of that idea. In her view modernity involves negotiation and accommodation as well as contestation and contradiction between individuals, communities and the state. It is within this modernity that notions of what is 'modern' and what is 'traditional' get framed and contested. What is implicit in this understanding is also that these negotiations happen against a specific historical and spatial backdrop. Kidambi (2007) has a similar idea of modernity when considering the development of Colonial Bombay. In his view modernization is "a contested and contingent set of outcomes that flowed from the contradictory currents generated by the market, state and politics against a background of rapid technological change, demographic growth, urbanization and mass migration" (Kidambi, 2007: 2). Thus, here, modernity itself becomes a process in flux, generating and producing many different currents. Following from this, the idea of multiple modernities has often been used to deal with the contradictions observed within the contemporary modern world. In this world, spaces get produced and reproduced through different interpretations of the nature of current reality and the nature of the particular history of places.

\section{DESTABILIZATIONS, HYBRIDITIES AND ACCOMMODATIONS}

One way in which the complex and interlinked character of notions of tradition and modernity becomes apparent is through the way built forms in South Asia defied existing categorizations and expectations of fixed use and meaning. For example, in the context of the Colonial city the specific modern disciplines - sanitation regimes, urban planning schemes, schooling and education, were not always successful in eliminating, displacing or replacing other orders. Moreover, British intentions of the built environment were constantly destabilized by the use that they themselves made of these spaces, and were changed in the process of doing so. Thus British intentionality on a formal level, in terms of control of spaces and the effects they were supposed to produce, was being constantly contested in the lived experience of these spaces by both British and Indians (Chattopadhya, 2006). This also applied to the order of governance. In other words, the spaces and buildings took on a life of their own in a constant dialectic with the changing social experiences of the inhabitants.

For example, the fixing of the meaning and uses of space was a strong imperative of the Colonial spatial order. It has 
been argued that this prescriptive use of space came into direct conflict with the multi-functionality of space use in dwellings in South Asia. Similar, traditional, spatial patterns have also been noted in the Middle East. However, Chattopadhyay (2006) shows that it was not just the difference between the old use of space and this new order that created tensions. It was also the fact that when Europeans started living and working in the Colonial city, they adopted a multifunctionality of use in their residences and commercial establishments, for various reasons. One of these reasons, which Chattopadhyay looks at closely were the demands of trade and property transactions in the city. As the demand for housing fluctuated widely in Calcutta, residences were constantly being transformed into commercial spaces and vice versa, in order to have resale value. Which means that these spaces began to be designed in such a way as to facilitate the conversion of spaces into different kinds of uses.

As opposed to the planned hybridity and fusion of the architecture that served the various objectives of empire, one finds in the urban vernacular tradition of the subcontinent an interpretation of architectural forms that defied preconceived categories and the rationalist objectives of formalist design. It is here, in the ornament and sculptural details produced by local craftsman that one sees the contingent nature of so-called fixed and rational categories of the built form. As Mumtaz (1985) writes "when the traditional Sindhi stone carver turned to European classical architecture, he fashioned forms that would have delighted even the most outlandish Italian mannerist" (Mumtaz, 1985:147). In the urban vernacular of Karachi, one finds this constant juxtaposition of forms created by local craftsmen over classical frames (Figures 7, 8). This also happened in reverse, where certain European elements, like the bust of Queen Victoria would appear on traditionally framed buildings (Figure 9). There are various ways that the intentionality behind these forms can be viewed. It can be seen as the result of the cultural encounter between European and Indian building traditions. This encounter, however, to a considerable extent, was more of a usurpation and displacement of local cultural forms than a genuine exchange where Indian architectural forms became marginalized or subordinate to the European forms. However, as the theory of transculturation suggests, it is also "how subordinate and marginal groups select and invent from materials transmitted to them from a dominant or metropolitan culture" (Pratt, 1992:6). On the other hand, these efforts at hybridity can be seen as a way for the subaltern classes to express the constant tension they felt between the assertion, whether conscious or subconscious, of their own centuries old building

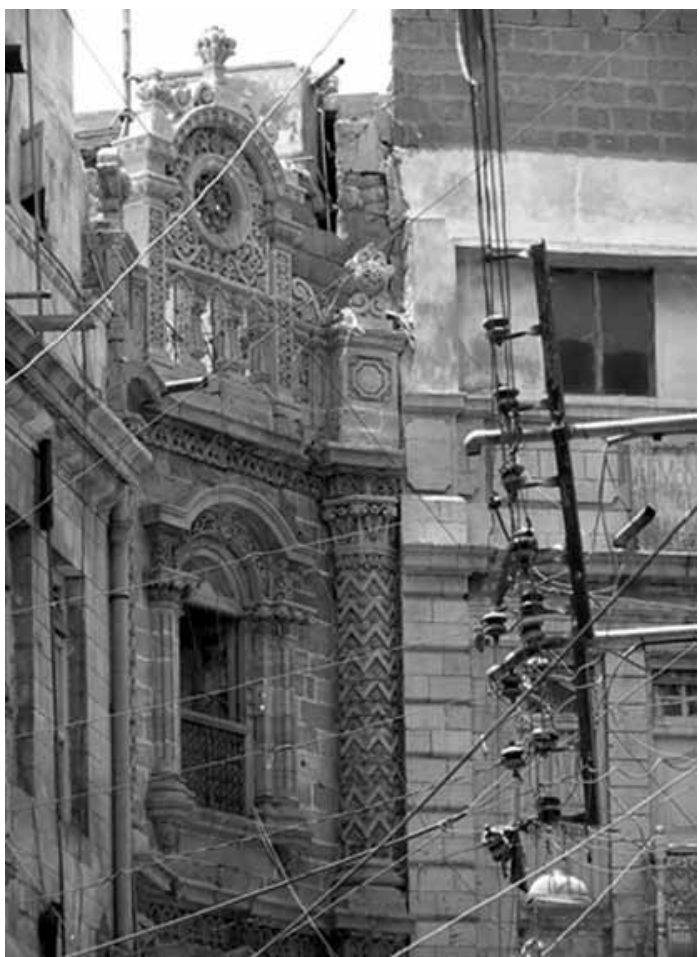

Figure 7: Building in Market Quarter, Saddar Town, Karachi. Source: Heritage Cell, Department of Architecture and Planning, NED University

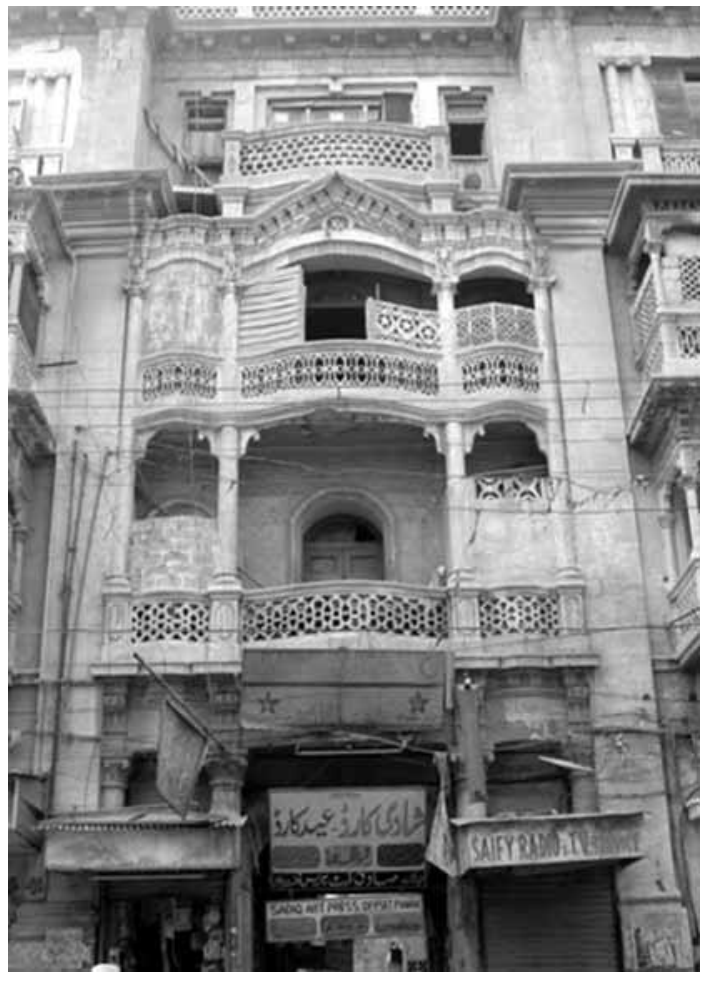

Figure 8: Building in Serai Quarter, Saddar Town, Karachi. Source: Heritage Cell, Department of Architecture and Planning, NED University 


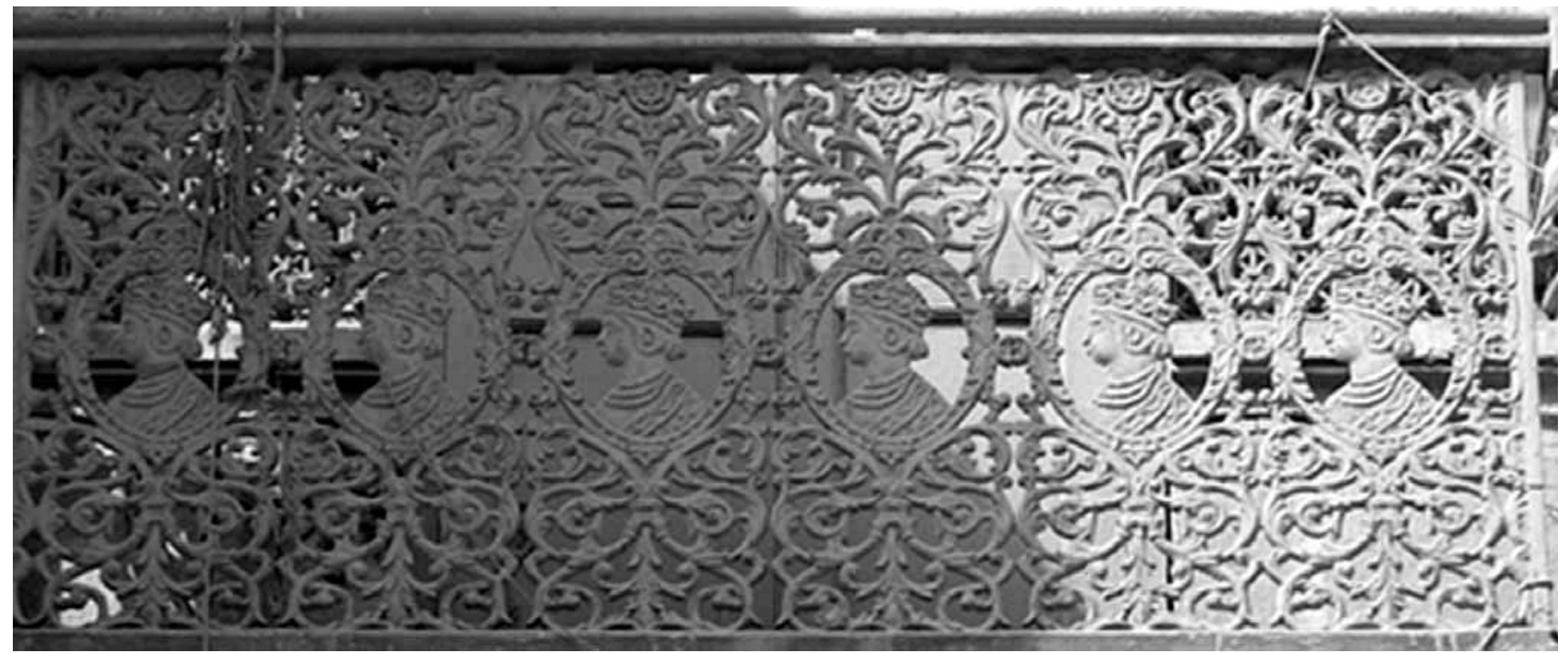

Figure 9: Bust of Queen Victoria in balcony detail on building in Old Town, Karachi. Source: Heritage Cell, Department of Architecture and Planning, NED University

practices against the desire to please and acknowledge the metropolitan culture. This tension has been explored at length in the historiography on South Asia, especially related to the way both resistance and accommodation marked the way Indians responded to Colonial rule.

To the British, these spontaneous attempts at hybridity were a source of discomfort because it was not the planned hybridity, for example in the form of the Indo-Saracenic style that served the objectives of empire. This hybridity implied, on the part of the 'native' a certain amount of knowledge of European architectural elements that allowed the native to play with it in inventive and creative ways. It implied a loss of control on the part of the rulers over the new forms and cultures that were emerging in the aftermath of the Colonial encounter.

This tension between intent and its unintended effects can be found in the development of Karachi's markets, for example. Baillie (1890:142) describes the Empress Market, a landmark building in Karachi, built in 1889, as having a "domestic gothic style." The market was built by a British engineer, James Strachan, while the contracting work was carried out by Walli Mahomed Jiwun and Dulloo Khejoo, two local contractors. It is indicative of the concession made by the Colonial rulers to the retention of certain cultural aspects of the native that Baillie calls this the 'domestic' gothic style, and also gives credit to the local contractors. As Wright (1987) has suggested, similar French Colonial practices were meant to appease local sentiments of ambivalence to foreign rule by making the visual culture produced under Colonialism appear as tolerant while attempting to make it popular (Pratt, 1992:6).

Continuing with Baillie, further indications of this kind of concession to local customs appears in his account of the development of markets in Karachi under British rule:

\begin{abstract}
"Sir John Gorst, M. P., in answer to a question put to him in the House of Commons recently stated that all bazaars in a Cantonement, other than "Regimental Bazaars" of which the chief customers are the civilian population, are called "Cantonement Bazaars" and the chief of these would be called the "Sudder Bazaar." The definition is not inaccurate, but it stops halfway. Sadr is an Arabic word which through certain transformations has come to mean chief, supreme and thus we get the sadr diwan adalat or chief civil court of India, but long before Cantonements were known, there were Sadr Bazaars throughout India" (Baillie, 1890:143).
\end{abstract}

Here, Baillie takes pains to explain the local origins of the bazaar and its name, both of which were retained under Colonial rule. He also concedes the way a bazaar differs from a market: 
"A bazaar is not a market, in our acceptation of the word, that is to say it is not a collection of stalls under one roof for the display of provisions and produce. A bazaar is a quarter containing a number of stores and shops, the property of distinct owners, but it is not unusual to find a market situated in its midst" (Baillie, 1890: 143).

The British did insert their own markets in the midst of the bazaars, though, and named them, which resulted in Karachi having a Boultan Market, a Soldier's Market and of course the Empress Market which opened to great fanfare in 1889 and which still exists and thrives in Karachi. These were the markets where the ladies of the military branch of society would go since their requirements could not be met in the regimental bazaars of the Cantonment. Hence, the hybrid market-bazaar became a popular urban form with elements of both British and Indian styles of design and function.

The form of the markets and the bazaars that contained them as well as the names given to them is an interesting example of the way in which Colonial interventions and practices became embedded in the urban fabric of the city. They continue to exist though their social forms and economic functions have changed, and new meanings are associated with them, whether it is the Empress Market as a landmark signifying a convenient transportation hub, or the Soldier Bazaar merely existing as a navigational marker for the city.

These new meanings contribute just as much to the urban identity of the city but often are seen as obstacles to the recovery of the 'authentic identity' of these places which attempt to recover their original meaning and intent. For Lefebvre (1992), space is a social product and attains meaning through its reproduction by people. The everyday lived experiences of people, rooted in the now, continuously change the meaning and associations around the built environment as a living dynamic history. Seen in this way, fixed notions and separations of what is considered 'historic' and what is not, becomes problematic.

Another example from the meanings associated with the built form in Karachi arises from an interesting narrative on the city written by Lokram Dodeja expressing his perceptions of the city during the pre-partition years:

"In the beginning Karachi was a fortress with two gateways, the gateway facing the sea was the Khara Darwaza (salt water gate) and the gateway facing the sweet water wells was the Meetha Darwaza (sweet water gate). At that time the walls of the fortress had disappeared. In the narrow streets between the two gates were the houses of the early businessmen (the Seth) and people of the chapar and sehta clans also used to live here. Around this the rest of the city lived in which there were people not just from Sindh but from all of Hindustan. There was an ancient ground by the name of Ram Bagh, about which it is said that in the Treta Yug, while traveling to Hinglaj, Ram, Lakshman and Sita rested in this spot. During the freedom struggle, from 1920 to 1947, this is where leaders would hold rallies, the martyrs of the Salt and Satyagraha Movements were martyred here and there were incidents of firing. I had bought a building towards the south of this spot, from the balcony of which I witnessed these historic events. This was also the place from where, during the Mutiny of 1857, Sindhi fishermen revolted against the British and were bound to the mouths of the canons and blown up. It is a pity that now, the name of this historic place has been changed from Ram Bagh to "Aaram Bagh" and so a symbol of Sindh's history and pride has been erased" (Dodeja, 2007).

Dodeja's description of the Old Quarter evokes the same kind of spatial patterns that have been found in other historic accounts on Karachi, in which the density of the settlement and its multi-ethnicity is highlighted. The most interesting part of this account, however, is the way Ram Bagh appears in the account. Ram Bagh is an open public space with which significant effects, both mystical and political are associated. The name literally means the Garden of Ram, one of the mythical Hindu gods. The story of Ram and Sita and their taking respite in Ram Bagh on their way to Hinglaj, a sacred Hindu place is known in the folklore on the city from long before the arrival of the British. For Dodeja, though, Ram Bagh has acquired a different significance during the Colonial years, where it has become associated with the repression of local revolts during the Mutiny and further repression during the Salt and Satyagraha Movements initiated by Gandhi during the years of the independence 


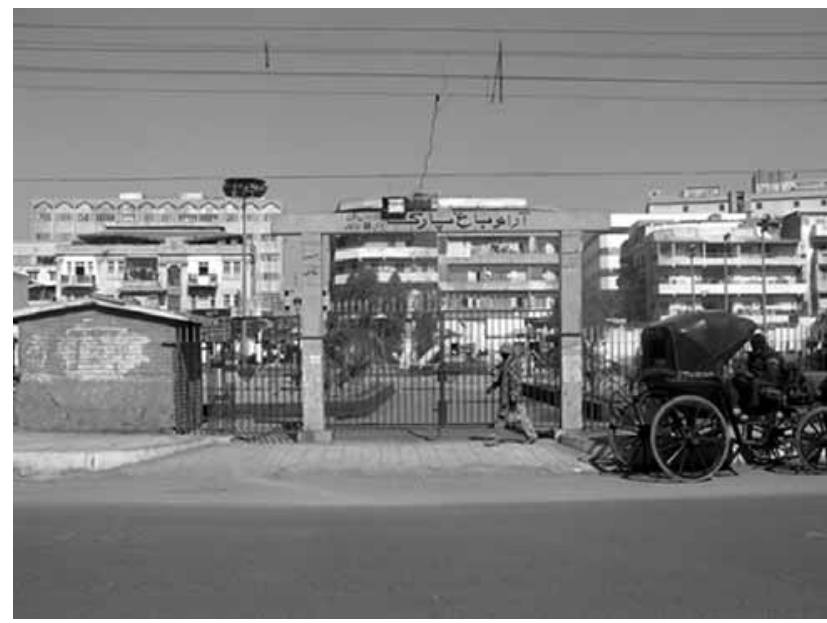

Figure-10: Entrance to Aaram Bagh in Saddar Town, Karachi.

struggle. The story of Ram Bagh does not stop there, it continues with the changing of its name to Araam Bagh, the Garden of Comfort, which Dodeja sees as an attempt to erase its proud history. The post-partition name change of the space is significant because it was a gesture towards the changing religious sentiment in the city. When half of the Hindu population of the city left after partition, the vacuum was filled by the arrival of Muslim refugees into the city from different parts of India. Overnight, the population of the city had been changed from almost $50 \%$ Hindu to majority Muslim. With communal tensions as well as nationalist pride on the rise, the city was slowly purged of reminders of its Hindu past (Figures 10, 11).

The different social meanings associated with this public space at different times show the dynamism of the sociospatial world of Karachi and the way that the local and the Colonial interacted to create new meanings and new contestations around space. For Dodeja the city does not seem to be demarcated in terms of the native and non-native. Even though he differentiates the 'old city' from the new, more modern city, in his accounting of his favourite spots around the city, there are both features of the European as well as spots that evoke some of the older forms. The city appears as an integrated whole in his account, with everyday experience relating to the British-built monuments and spaces as well as the non-British monuments and elements. It is to be kept in mind that Dodeja's account dates from the times of British rule and not after independence. He experiences the Colonial buildings - the Frere Hall, the Max Denso Hall and the Mereweather Tower - as 'magnificent.' Although he does note the fact, that as a native, he had to procure special permission to become a member of the Frere Hall

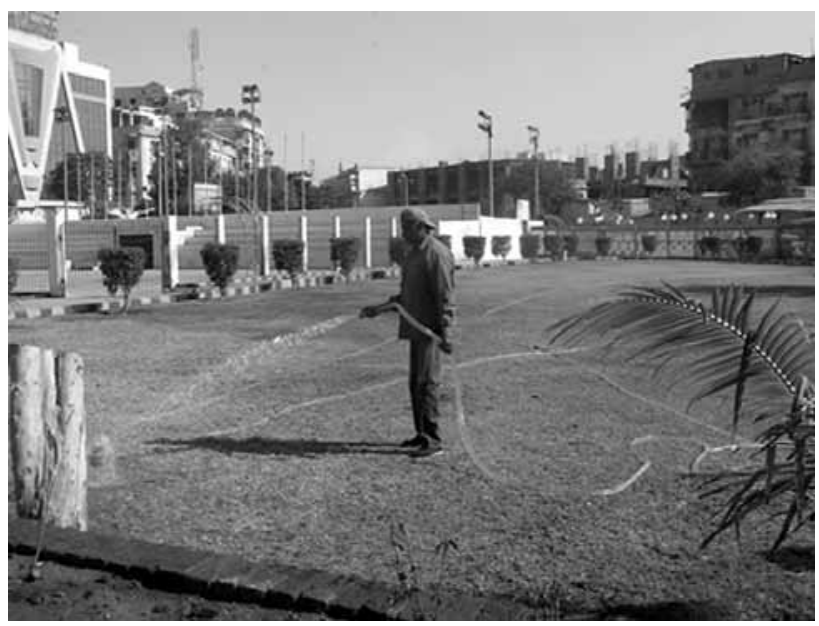

Figure-11: Another view of Aaram Bagh.

library which was reserved exclusively for Europeans. A significant part of Dodeja's account deals with descriptions of the various Hindu temples around the city and the activities and festivals that take place in these spots.

Based on these accounts an argument can be made for the persistence of the old spatial order at the same time as the Colonial spatial order, initially an external order meant to produce effects of power, becomes linked in certain ways with the older forms. This happened on the material level of architectural styles and spatial forms but also in the way social meanings of spaces were constructed. This was not necessarily an effect that the Colonial order meant to achieve, though. Even though Colonial governmentality attempted a certain kind of integration with the local in order to create legitimacy, an example like the significance of Ram Bagh for Dodeja shows the way reproductions of space happened outside of its conceived meanings. For Dodeja, Ram Bagh evokes the old spatial order in the story of Ram and Sita and Pre-Colonial meanings associated with the space. It then takes on a meaning arising out of the effects of Colonial rule and the contestation that results from it and yet another meaning resulting from its post-partition transformation.

\section{CONCLUSION}

In South Asia notions of traditional and modern arose in the context of the fulfillment of Colonial objectives. These notions were then reproduced in the framework of PostColonial nationalist ideologies and intentions. However, an important and overlooked factor that continuously and anonymously reproduces living environments is the constant reproduction and reinterpretation of these spaces by people 
themselves in everyday living. This reproduction of space reveals itself in the architectural detailing created by unknown and un-named craftsmen as well as the memories and meanings associated with urban spaces. Here, several histories are underwritten in the production of a single space, whether it is the residential façades of Bombay or Karachi, or a space like Ram Bagh that evokes multiple meanings. This is when fixed categories of traditional and modern are destabilized and history becomes an experience that is constantly reproduced and reinvented. In this history, modernity itself is the process that has produced the conceptual framework for understandings of the past and the criteria for what is traditional and what is not. Thus, an active engagement with the multiple meanings and histories associated with the built environment in South Asia requires breaking away from the duality of categories of the 'modern' and the 'traditional.'

\section{REFERENCES}

Aijazzuddin, F. S., 1992, Historical images of Pakistan. Ferozsons Ltd, Karachi.

Arnold, D., 2006, The tropics and the travelling gaze: India, landscape and science, 1800-1856, University of Washington Press, Seattle and London.

Baille, A. F., 1890, Kurrachee: past, present and future, Oxford University Press, Karachi.

Blake, S., 1990, Shahjahanabad: The sovereign city in Mughal India, 1639-1739, Cambridge University Press, Cambridge.

Burton, R. F., 1851, Sindh and the races that inhabit the valley of the Indus, Oxford University Press, Karachi.

Chattopadhya, S., 2006, Representing Calcutta: modernity, nationalism and the Colonial uncanny, Routledge, Oxford.

Chakrabarty, D., 1992, "Postcoloniality and the artifice of history: who speaks for "Indian" pasts?" Representations 37 , 1-26.

Dodeja, L. R. 1978 'Karachi ke theerath aur doosray maqamat' in Kamal, A. (eds.). Karachi ki kahani, City Press, Karachi.

Kidambi, P., 2007, The making of an Indian metropolis: Colonial governance and public culture in Bombay 1890-1920, Ashgate, London.

Lefebvre, H., 1992, The production of space, Blackwell, New York.

Metcalf, T., 1984, 'Architecture and the representations of empire 1860-1910' Representations 6(Spring), 37-65.

Metcalf, T., 1989, An imperial vision: Indian architecture and Britain's Raj, University of California Press, Berkeley.

Mumtaz, K. K., 1985, Architecture in Pakistan, Concept Media, Singapore.

Pratt, M. L., 1992, Imperial eyes: Travel writing and transculturation, Routledge, London.

Wright, G., 1987, 'Tradition in the service of modernity: architecture and urbanism in French Colonial policy 1900-1930', The journal of modern history 59(2), 291-316. 